A N NALES

UNIVER S T A T IS MARIAE CURIE-SKŁODOW S A LUBLIN - POLONIA

VOL. XXIX, 2

SECTIO J

2016

${ }^{1}$ Drohobych Ivan Franko State Pedagogical University, Ukraine

${ }^{2}$ Lviv Ivan Franko National University, Ukraine

${ }^{1}$ LESIA VASYLENKO, ${ }^{2}$ IGOR VASYLENKO

vasyl.les@yandex.ru

\title{
Theoretical Basis of Psycho-Pedagogical Support of Personal and Professional Development of the Future Teacher
}

\footnotetext{
Teoretyczne podstawy psychologiczno-pedagogicznego wsparcia osobowego i zawodowego rozwoju przyszłych nauczycieli
}

\begin{abstract}
In the article there is given the concept of support of the personal and professional development of the future teacher. Authors presented the aim of the process: formation of future teachers, updating the set of personal qualities of the students that leads to the development of their subjectivity. Authors distinguished also the principles of the development of future teachers: e.g. taking into account the needs of the individual related to self-organizing and self-development; recognition of an identity and self-worth of the students.
\end{abstract}

Key words: psycho-pedagogical technology; support of professional training; professiogenesis; personal and professional development

\section{INTRODUCTION}

The development of a society, above all inscientific-technical and human kind spheres, set new challenges for the higher education from changing orientation of thetrainingfuture professionals to form their professional knowledge and skills to ensure favourable conditions for the harmonious balanced professional and personal development of students. This process should involve increasing their motivation resources, self-regulation, self-organization and self-development. These 
apply especially to future teachers, whose professional effectiveness depends on the integral willingness to achieve the abovementioned features, the identity of the individual, which, in turn, ensures the success of the professional development at the stage of studying at a higher educational institution. Thus, the basic conditions determining the solution of the outlined problem are to create a special developing environment at the university, a space of mutual support and cooperation, a real subject-subjective relations designed to build students' own professional development, a prevention against destructive professional and personal events, updating internally personal potential, i.e. the introduction of the technology of the psychological support.

The phenomenon of the psychological support is comprehended in modern psychology and pedagogy in the context of an innovation in education. Summarizing existing approaches, we would like to note that the psychological support is a system of measures aimed at creating conditions for successful learning and personal development activities (Zeyer 2003a; Krinchik 2005). The result of such a psychological support is full implementation of the mental capacity of the individual, the formation of the psychological knowledge for making appropriate choices and overcoming difficulties in a personal and professional life (Antilogova 2005).

\section{PSYCHOLOGICAL SUPPORT FOR THE APPROPRIATE PROFESSIOGENESIS}

Most researchers stick to the point that an individual psychological support of the professional training is of great importance, especially at the initial stage. In our opinion, this phenomenon is due to the fact that in recent years in education, including the professional, a new paradigm "student-centred learning" is becoming more and more important. Thus, a system of factors forming students-centred education becomes a personal development of the individual in the process of interaction of all subjects of the study, based on their previous experience, the personal characteristics, and a specific training material, the educational space and so on.

The studies by E.F. Zeyer, N.S. Glukhanyuk proved that at the initial stages of any professional learning, the source of the professional development is the level of a personal development. At the later stage, the ratio of the personal and professional development becomes uneven in the dynamics. At the stage of professionalism, the professional development of the individual begins to dominate over the personal one and defines it (Glukhanyuk 2005; Zeyer 2003b). The main objects of the professional development of a specialist are the following integral features: social and professional orientation, professional competence, professionally important physiological qualities of an individual (Vasyl'kov 2009, pp. 186-195).

Despite the considerable interest of scientists inthe issues of success of professiogenesis of future teachers, the role of the psychological service of the universi- 
ty in their personal and professional development, nowadays the opportunities of disciplines of psychological cycle for the personal and professional development of the future teachers are not fully defined. The problem of the psychological support of the personal and professional development of future teachers in the study of psychology is manifested in the absence of theoretically and methodologically determined consolidated model, developed and experimentally tested technologies of psychological and educational support.

The need to study and address the psychological support to the personal and professional development offuture teachers in higher education in the study of general, social, developmental, educational psychology, its relevance and appropriateness caused contradictions:

- The question of the preparation of highly qualified society, competitive, capable of continuous self-improvement teacher, who has been developed successfully as a person and a professional versus the lack of the national higher education system to ensure the harmonious personal and professional development;

- Knowledge of a modern psychological science of complexity, duration and the personal and professional development of future teachers versus the lack of an integrated psychological and pedagogical technologies supporting the personal and professional development of future professionals;

- Practice of teaching psychological disciplines at the university, which aims at transferring knowledge to the students, developing their abilities and skills versus the necessity to create conditions that will boost the mechanisms of students' personal and professional development and self-development as well. As a result, there is a narrowing of a wide range developmental opportunities of the psychological disciplines.

Therefore, the subject of our study is the psycho-pedagogical technology supporting the personal and professional development of future teachers in the field of psychological disciplines. Its development should be based on the principles taking into account the individual's needs for self-organization and self-development; recognition of an identity and self-worth of the student, who from the beginning is the subject of the study of the psychological support.

\section{THE STRUCTURE OF SUPPORT OF THE PERSONAL AND PROFESSIONAL DEVELOPMENT OF FUTURE TEACHERS}

A holistic understanding of the nature of maintenance the personal and professional development of future teachers in the field of psychological disciplines in higher education can be organized by the development and implementation of the psycho-pedagogical technology support, which includes: a theoretical, meth- 
odological and empirical study of scientific problems; creating a structural and functional support model that contains the characteristics of its main components (goals, objectives, functions, actors, stages, aspects, forms, ways, methods and means of implementation support); a methodical support in the field of psychological disciplines; an assessment of the effectiveness, conditions and ways to optimize support of subjects of educational process in the seminar room for psychology.

Recognizing a student is not an object but a subject of educational and professional activities, it is worth remembering that nothing can be changed in the student's inner world without his or her own will and desire. We have no right to influence students with specific methods and techniques without their permission. We must interact with them, offering a variety of solutions to a number of problems. As the M.R. Bityanova claims, a paradigm shift from an "aid" to a "facilitate", the most productive in education, is realized through psychological and pedagogical support (Bityanova 2004, p. 297).

In the context of our study, the notion of supporting the personal and professional development of future teachers is defined as a system of measures aimed at creating - during the lectures, laboratory and practical classes on psychology - the conditions for taking the subject named Development. This subject (Development) ought to enable future teachers to comprehend the possibilities and take requirements of modern society for their professional activities; assess and adequately correlate their individual features to the requirements of the profession; competently solve educational and professional objectives; actualize the potential of the individuals. The purpose of this support acts formatively for future teachers, updating the set of personal qualities of students, which leads to the development of their subjectivity. Development of the subjectivity of future teachers must be provided for the establishment of the psycho-pedagogical conditions that are the basis for an activation of self-awareness, self-knowledge, self-assessment, self-control, self-determination and self-development. The psycho-pedagogical support should facilitate the consistent deployment of the elements of future specialists' subjectivity: processing of their own experience, enhancing independence and ability to self-determination. These indicators carrying out the relevant formative influences are the subjective qualities: an internal locus of control, the ability to take conscious responsibility for their own choices, actions, development, meaningful life, autonomy, positive internal training and professional motivation, professional identity, and self-actualization.

The leading idea of our study is, that according to science-based and developed technology, we should support the personal and professional development of future teachers in the field of psychological disciplines. It should be carried out systematically and scientifically justified on the proposed model. 
We believe that the most effective organizational model of the abovementioned support should embrace the actualization of the developmental potential of psychological education, its content, use of interactive training methods during general, social, developmental and educational psychology lectures, laboratory and practical classes, a preparation and an implementation of the individual programs of the personal and professional development, a reflective analysis of the professional activities in the course of the practice.

\section{CONCLUSIONS}

The conditions for the most efficient support of the personal and professional development of future teachers in the field of psychological branches are:

- Commitment to the necessary level of the psychological knowledge (the knowledge of psychological foundations of educational and professional activities, the ability to analyse the results of students' own educational and professional activities; growing competence in the field of interpersonal relations between the teacher and students, the ability to determine ways and means of their own further development) and the competence (personal reflection that allows one to recognise specific personal potential, an efficient design of someone's life strategy, self-regulation, selfcontrol, etc.);

- Formation - under the influence of positive support - guidelines for continuous education and self-education;

- Willingness to learn new information and implement this in different areas of practice;

- Knowledge and practical skills in the field of self-education and self-development;

- Personal reflection, awareness of the barriers, or obstacles and promotion of the development and self-development;

- A high level of self-actualization needs;

- Willingness to implementation social activities;

- Availability of a high enticement to activities associated with higher levels of professional knowledge and skills.

All of the abovementioned is directly related to the reflection upon the students' need to develop such capacity as the ability to assess their potential objectively, recognize and accept the modern requirements of the society to the profession and to the adequate assessment and correlation of their individual features to the requirements of the profession, setting realistic goals, defining the ways to achieve them and predicting the results.

Thus, the personal and professional development of the teacher in terms of such a training would be more effective, if the leading organizational forms and 
methods of its implementation were supported in the course of psychological disciplines educational cycle. In this case, the content basis for the personal and professional development of the future specialist should create certain psychological and pedagogical conditions that will trigger the formation of the important personal and professional qualities.

Scientific substantiation of the technology support of the personal and professional development of future teachers in the field of psychological disciplines, development model and its implementation in the process of professional training are essential to solving the scientific problems of higher education within this area.

\section{ROMANISED REFERENCES}

Antilogova, L.N. Psikhologicheskoye soprovozhdeniye v vuze kak odno iz napravleniy professional'nogo stanovlennya studentov, "Vestnik Kemerovskogo gosudarstvennogo universiteta", no. 2 (22), Kemerovo 2005.

Bityanova, M.R., Organizatsiya psikhologicheskoy raboty v obrazovanii, Izdatel'stvo Sovershenstvo, Moskva 2004.

Glukhanyuk, N.S., Psikhologiya professionalizatsii pedagoga: monografiya, Izdatel'stvo RGPPU, Yekaterinburg 2005.

Krinchik, Ye.P., K probleme psikhologicheskogo soprovozhdeniya professional'nogo stanovleniya studentov-psikhologov, "Vestnik Moskovskogo un-ta", Seriya 14, Psikhologiya, 2005, no 2.

Vasyl'kov, V.M., Psykholoho-pedahohichni osoblyvosti profesiynoyi pidhotovky pedahohichnykhkadriv v umovakhsuchasnoho osvityans'koho prostoru, "Naukovyy chasopys NPU imeni M.P. Drahomanova", Seriya 12, Psykholohichni nauky no. 28 (52), Zbirnyk naukovykhprats, Kyiv 2009.

Zeyer, E.F., Psikhologiya professional'nogo obrazovaniya: uchebnoye posobiye, Izdatel'stvo Moskovskogo psikhologo-sotsial'nogo instituta, Moskva 2003a.

Zeyer, E.F., Psikhologiya professiy. Uchebnoye posobiye dlya studentov vuzov, 2 izdaniye, Delovaya kniga, Moskva 2003b.

\section{STRESZCZENIE}

W artykule omówiono zagadnienie wsparcia osobowego i zawodowego rozwoju przyszłych nauczycieli. Skoncentrowano się m.in. na celu tego procesu, którym jest kształcenie przyszłych nauczycieli i modernizowanie zestawu osobistych cech studentów, co ma prowadzić do rozwoju ich podmiotowości. Autorzy wyróżnili również zasady rozwoju przyszłych nauczycieli, np. branie pod uwagę potrzeb jednostki dotyczących samoorganizowania się i samodoskonalenia, uznanie tożsamości i wartości osobowych uczniów.

Słowa kluczowe: psycho-pedagogiczna technologia; wsparcie przygotowania zawodowego; profesjogeneza; osobowy i zawodowy rozwój 